\title{
PHOSPHORUS FERTILIZATION AND HARVEST INTERVALS INFLUENCE ENERGETIC AND PHYSICAL PROPERTIES OF BRIQUETTES AND LARGE BRANCHES OF MATE ${ }^{1}$
}

\author{
Delmar Santin $2^{*}$, Marcelino Breguez Gonçalves Sobrinho ${ }^{3}$, Angélica de Cássia Oliveira Carneiro ${ }^{4}$, Eliziane \\ Luiza Benedetti ${ }^{5}$ and Nairam Félix de Barros $^{6}$

\footnotetext{
${ }^{1}$ Received on 28.07.2015 accepted for publication on 16.09.2016.

${ }^{2}$ Cambona Consultoria e Treinamento Agroindustrial Ltda, Santa Terezinha De Itaipu, PR - Brasil. E-mail: $<$ desantinflorestal@yahoo.com.br>.

${ }^{3}$ Universidade Federal dos Vales do Jequitinhonha e Mucuri, Mestrado em Ciência Florestal, Teófilo Otoni, MG - Brasil. E-mail: <marcelinobreguez@yahoo.com.br>.

${ }^{4}$ Universidade Federal de Viçosa, Departamento de Engenharia Florestal, Viçosa, MG - Brasil. E-mail: <cassiacarneiro1@gmail.com>.

${ }^{5}$ Instituto Federal de Santa Catarina, Canoinhas, SC - Brasil. E-mail: <elibettiagro@yahoo.com.br>.

${ }^{6}$ Universidade Federal de Viçosa, Departamento de Ciências do Solo, Viçosa, MG - Brasil. E-mail: <nfbarros@ufv.br>.
} \\ *Corresponding author.
}

\begin{abstract}
In mate crop, the commercial part consists of leaves and thin branches, while the large branches (LB) are considered unused residues and left in the field, although they may have potential for use as energy. The objective of this paper was to evaluate the influence of phosphorus fertilization and harvest interval in productivity of mate large branches and in their physical and energetic properties, as well as in derived briquettes. In a seven-year-old plantation, doses of $0,20,40,80,160$ and 320 kg.ha-1 of $\mathrm{P}_{2} \mathrm{O}_{5}$ were applied considering harvest intervals of 12,18 and 24 months. Dry mass, average diameter, P content, and physical and energetic properties of LB were determined. With LB, after its transformation into particles and briquetting, physical and energetic properties were determined, as well as $\mathrm{P}$ availability in soil. The phosphorus fertilization increased LB productivity in larger harvest intervals, increasing the amount of energy produced per unit of area, but did not change basic density and gross calorific value of wood. Mate harvest intervals did not affect the apparent density and calorific value of briquettes produced by LB. LB harvested at intervals of 18 and 24 months produced wood with higher basic density and gross calorific value. LB or briquettes have adequate energetic and physical properties, being technically a plant residue with great potential for use as energy.
\end{abstract}

Keywords: Plant residues; Renewable energy; Ilex paraguariensis.

\section{ADUBAÇÃO FOSFATADA E INTERVALOS DE COLHEITA INFLUENCIAM AS PROPRIEDADES ENERGÉTICAS E FÍSICAS DE BRIQUETES E DE GALHOS GROSSOS DE ERVA-MATE}

RESUMO - Na colheita da erva-mate, a parte comercial é composta por folhas e galhos finos, enquanto os galhos grossos (GG) são considerados resíduos e deixados no campo, mas que podem apresentar potencial para uso como energia. O objetivo do trabalho foi avaliar a influência da adubação fosfatada e do intervalo de colheita na produtividade de galhos grossos de erva-mate e em suas propriedades físicas e energéticas $e$, de briquetes deles derivados. Em um erval com sete anos aplicaram-se doses de 0, 20, 40, 80, 160 e 320 $\mathrm{kg} . \mathrm{ha}^{-1}$ de $\mathrm{P}_{2} \mathrm{O}_{5}$ e utilizandos os intervalos de colheitas de 12, 18 e 24 meses. Determinou-se a massa seca, diâmetro médio, teor de P e propriedades físicas e energéticas dos GG. Com os GG, após sua transformação em particulas e briquetagem, foram determinadas propriedades físicas e energéticas. Determinou-se, ainda, a disponibilidade de P no solo. A adubação fosfatada aumentou a produtividade do GG em intervalos maiores de colheita, aumentando a quantidade de energia produzida por unidade de área, mas não alterou a densidade básica e poder calorífico superior da madeira. Os intervalos de colheita da erva-mate não interferiram na 
densidade aparente e no poder calorifico de briquetes produzidos pelo GG. Os GG colhidos com intervalos de 18 e 24 meses produziram madeira com maior densidade básica e poder calorífico superior. Os GG ou os briquetes apresentam propriedades energéticas e fisicas adequadas, sendo tecnicamente, um resíduo vegetal com grande potencial para uso como energia.

Palavras-chave: Resíduo vegetal; Energia renovável; Ilex paraguariensis.

\section{INTRODUCTION}

Wood in its natural form or made into briquettes, pellets or other type of particulate material can be used to generate energy for various uses, but it is still little used in Brazil, although it has great significance in world exports of forest products (Coelho Jr. et al., 2013). In Brazil, the energy from forest biomass derives mainly from planted forests, especially those from the Eucalyptus, but by-products from other crops have potential to produce energy. This is the case of mate (Ilex paraguariensis St. Hill.), which generates significant amounts of large branches in its harvest. Little is known about the energetic potential of this residues and what the influence of cultivation practices is, such as fertilization and crop management, in its calorific value. Santin (2013) found that fertilization significantly increases the production of various mate components, so that their proportions are influenced by intervals between harvests. In general, longer harvest intervals allow greater production of more woody components than the shorter ones (Santin et al., 2015). Commonly, when harvest is carried out at an interval of 18 or 24 months, the significant volume of large branch produced becomes an obstacle to site cleanup, requiring, in many cases, its removal from the site. Many producers end up using part of this residue as a source of energy on their own farms (Santin, 2008), although little is known about its energetic properties.

Wood for energy, in general, should have a high density, high lignin content, high calorific value, low moisture, and low mineral content (Barcellos et al., $2005)$. These qualities vary according to the species (Quirino et al., 2004) and forestry practices (Barcellos et al., 2005). The age of trees also interferes considerably in the properties of wood, since several transformations, such as chemical composition, and physical and anatomical characteristics, occur as trees age (Carneiro et al., 2014). However, the age of wood can interfere with its gross calorific value (Brand et al., 2014; Carneiro et al., 2014) or not (Protásio et al., 2014). Typically, the older the plant is, the higher the wood basic density is and, consequently, the greater the amount of energy stored per $\mathrm{m}^{3}$ (Carneiro et al., 2014).

Fertilizers can affect, directly or indirectly, the energy potential of wood as observed for E. saligna by Berger (2000). The author reports that fertilization increased wood density and, consequently, calorific value thereof. As for other species of Eucalyptus, this effect was not observed, with an increasing occurring only in the amount of wood produced per area (Vale et al., 2000).

Wood residues can be used processed or not as source of energy. The production of briquettes from wood residues has proven viable in various forest industries as a way to add value to these products. According to Quirino et al. (2012), briquetting is a mechanical process that converts a vegetable residue of low density into a fuel of higher energy density, low moisture, and regular and uniform grain size, facilitating transport, storage and automatic feeding processes of industrial boilers.

Given the above, the objective of this study was to evaluate the influence of phosphorus fertilization and harvest interval in productivity of mate large branches and in their physical and energetic properties, as well as in derived briquettes.

\section{MATERIALS AND METHODS}

The experiment was carried out in January 2009 in a seven-year-old mate plantation in a spacing of $2 \times 2 \mathrm{~m}$, located in São Mateus do Sul, Paraná, Brazil, at the longitude $50^{\circ} 22^{\prime} 58^{\prime \prime} \mathrm{O}$ and latitude $25^{\circ} 52^{\prime} 27^{\prime \prime}$ $\mathrm{S}$. The soil is an alic dark-red Latosol of low fertility (Table 1), that had never received liming or fertilizing.

Treatments were arranged in a factorial $3 \times 6$, in a split plot design, consisting of three harvest intervals (in plot) and six levels of $\mathrm{P}_{2} \mathrm{O}_{5}$ (in subplot). Each experimental unit consisted of 10 useful plants, with two border strips. Treatments were arranged in a randomized block design, with five replications. Crops with intervals of 12, 18 and 24 months, and phosphorus 
Table 1 - Clay content and soil chemical properties of the experimental site in São Mateus do Sul, PR, in a soil from 0 to $20 \mathrm{~cm}$ of depth.

Tabela 1 - Teor de argila e propriedades químicas do solo de 0 a $20 \mathrm{~cm}$ de profundidade no local do experimento, São

\begin{tabular}{|c|c|c|c|c|c|c|c|c|c|c|c|}
\hline $\mathrm{CO}$ & Clay & \multirow{2}{*}{$\begin{array}{c}\mathrm{pH} \\
\mathrm{H}_{2} \mathrm{O}\end{array}$} & $\mathrm{P}$ & $\mathrm{K}^{+}$ & $\mathrm{Ca}^{2+}$ & $\mathrm{Mg}^{2+}$ & $\mathrm{Al}^{3+}$ & $\mathrm{H}+\mathrm{Al}$ & $\mathrm{CTC}$ & $\mathrm{V}$ & $\mathrm{m}$ \\
\hline$\overline{-\cdots}$ & $r^{-1}-$. & & $--m$ & $1^{-3}--$ & \multicolumn{5}{|c|}{ 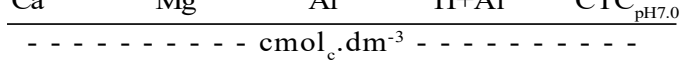 } & \multicolumn{2}{|c|}{ - - - \% - - } \\
\hline 31.2 & 770 & 3.92 & 1.31 & 56.80 & 0.95 & 0.39 & 4.47 & 15.78 & 17.27 & 8,6 & 71.2 \\
\hline
\end{tabular}

Extractors: Mehlich-1 (HCl 0.05 mol. $\mathrm{L}^{-1}+\mathrm{H}_{2} \mathrm{SO}_{4} 0.0125$ mol. $\left.\mathrm{L}^{-1}\right)$ : $\mathrm{P}$ and $\mathrm{K}$ and $\mathrm{KCl}\left(1 \mathrm{~mol} . \mathrm{L}^{-1}\right)$ : $\mathrm{Ca}, \mathrm{Mg}$ and $\mathrm{Al}$.

doses of $0,20,40,80,160$ and $320 \mathrm{~kg} \cdot \mathrm{ha}^{-1}$ of $_{2} \mathrm{O}_{5}$, supplied with triple superphosphate, were evaluated. At the time of experiment installation, 1 t.ha $\mathrm{ha}^{-1}$ of dolomitic limestone was applied superficially in total area, according to MANUAL (2004). As a N-and-K-based fertilization, $80 \mathrm{~kg} \cdot \mathrm{ha}^{-1}$ of $\mathrm{N}$ and $\mathrm{K}_{2} \mathrm{O}$, respectively, were applied in the form of urea and potassium chloride.

The dose tested and basic fertilization were applied in plots, being held in the crown projection area without incorporation, always in January and September. For crops with a 12-month-interval, doses of $\mathrm{P}_{2} \mathrm{O}_{5}$ and basic fertilization were split twice. For crops with intervals of 18 and 24 months, the $\mathrm{P}_{2} \mathrm{O}_{5}$ doses were divided in three times, while the basic fertilization was divided twice (first two applications) (Table 2).

The harvest at intervals of 12,18 and 24 months was reaped respectively in January 2010, July 2010, and January 2011 (Table 2). It consisted of removing about $95 \%$ of green mass that grew from the previous harvest, from which commercial mate (leaf + thin branch) was separated from large branch (LB), and the mass of LB green determined. Cutting for harvest was performed between 10 and $15 \mathrm{~cm}$ above the position of last pruning. It was considered as LB the branches with a diameter greater than $7 \mathrm{~mm}$, approximately. During the harvest, it was taken a representative sample of LB per plot, composed of 15 pieces of approximately $10 \mathrm{~cm}$ in length, in equal portions of representative LB base, middle and apex, where average diameter was determined (using a caliper, in $\mathrm{mm}$ ), as well as green and dry mass $\left(65^{\circ} \mathrm{C}\right)$. The samples, after being dried, were manually transformed into sticks with the aid of stainless steel knife, passed in a Wiley mill with a sieve of $0.5 \mathrm{~mm}$ opening and, subsequently, chemically analyzed for P. For total P content, it was used nitropercloric digestion and determination by colorimetry, through phosphomolybdate reduction by vitamin C (Braga and De Filippo, 1974).

It was also collected a soil sample at $0-20 \mathrm{~cm}$, in each plot, consisting of 15 simple samples taken in crown projection area of the plants. After being airdried and passed through a 2-mm mesh sieve, the soil was subjected to Mehlich-1 extractor (De Filippo; Ribeiro, 1997), and P content was determined by colorimetry, through phosphomolybdate reduction by vitamin $\mathrm{C}$ (Braga; De Filippo, 1974).

LB samples were dried at $65^{\circ} \mathrm{C}$ until a constant weight in the farmhouse, next to the experiment, and processed in laboratories of the Federal University of Viçosa, Minas Gerais, Brazil, where physical and chemical properties of the material were determined.

LB basic density was determined by immersion in water, by using a hydrostatic balance and noting the volume displaced, according to ABNT NBR 11941 (ABNT, 2003). Gross calorific value (GCV) was determined according to standard NBR 8633 (1984), by using an adiabatic bomb calorimeter. The ash content was obtained from LB samples, ground and sieved to a grain size of approximately $0.2 \mathrm{~mm}$, following the procedures recommended by ABNT NBR 8112 (1983). For the

Table 2 - Fertilizer splitting and time of application, and harvest time according to mate harvest intervals.

Tabela 2 - Parcelamento e época de aplicação da adubação e época de colheita da erva-mate conforme intervalo de colheita.

\begin{tabular}{|c|c|c|c|c|c|c|c|}
\hline \multirow{3}{*}{$\begin{array}{l}\text { Harvest } \\
\text { Interval } \\
\text { Months }\end{array}$} & \multicolumn{6}{|c|}{ Fertilizing splitting and time of application of doses of $\mathrm{P}_{2} \mathrm{O}_{5}$} & \multirow{3}{*}{$\begin{array}{l}\text { Harvest } \\
\text { Period }\end{array}$} \\
\hline & \multicolumn{2}{|c|}{$1^{\text {st }}$ parcel } & \multicolumn{2}{|c|}{$2^{\text {nd }}$ parcel } & \multicolumn{2}{|c|}{$3^{\text {rd }}$ parcel } & \\
\hline & $\%$ dose $\mathrm{P}_{2} \mathrm{O}_{5}$ & Period & $\% \operatorname{dose} \mathrm{P}_{2} \mathrm{O}_{5}$ & Period & $\% \operatorname{dose} \mathrm{P}_{2} \mathrm{O}_{5}$ & Period & \\
\hline 12 & 50.0 & $\operatorname{Jan} / 2009$ & 50.0 & Sept/2009 & $=$ & - & $\operatorname{Jan} / 2010$ \\
\hline 18 & 33.3 & $\operatorname{Jan} / 2009$ & 33.3 & Sept/2009 & 33.3 & $\mathrm{Jan} / 2010$ & $\mathrm{Jul} / 2010$ \\
\hline 24 & 33.3 & Jan/2009 & 33.3 & Sept/2009 & 33.3 & Set/2010 & Jan/2011 \\
\hline
\end{tabular}


production of briquettes, LB wood was converted into smaller fragments and, subsequently, into particles by using hammer mill.

For determinations relating to energetic properties of LB, it was initially quantified the GCV of LB samples corresponding to doses 0 e $320 \mathrm{~kg} \cdot \mathrm{ha}^{-1}$ of $\mathrm{P}_{2} \mathrm{O}_{5}$, so that the data were subjected to analysis of variance. As fertilization did not interfere statistically with GCV, samples from other doses of $\mathrm{P}_{2} \mathrm{O}_{5}$ were not analyzed.

Briquettes were produced with particles at the average size of $7.94 \mathrm{~mm}$ of length and $1.12 \mathrm{~mm}$ of thickness in a laboratory briquetter, Lippel LB-32 model. The following briquetting conditions were used: temperature of $120^{\circ} \mathrm{C}, 5$-minute pressing time and 5-minute cooling time, with a pressure of 1500 PSI. The mass used for each briquette production was 17 grams, while the average hygroscopic equilibrium humidity of particle was approximately $9 \%$, determined according to the standard ABNT NBR 9484 (1986).

The determination of apparent density of the briquettes was performed by weighing and subsequent immersion of briquettes in mercury, obtaining the displaced volume, according to the hydrostatic balance method, described by Vital (1984). For energy density and amount of energy per unit of volume of briquettes, the value was obtained by multiplying gross calorific value by apparent density of the briquettes, presented in Gcal.ha ${ }^{-1}$.

For determination of maximum tensile strength of the briquettes, a Losenhausen universal testing machine was used. The briquettes were subjected to continuous and progressive pressure until the breaking load. The machine applies a force on the side of the briquette with a piston with predetermined test speed of $6.0 \mathrm{~mm} \cdot \mathrm{min}^{-1}$. The methodology adapted from the standard ISO 11093-9 (2009) was used, since there is no specific standard for briquettes.

Prior to the production and analysis of briquettes, the calorific value of samples corresponding to the doses 0 and $320 \mathrm{~kg} \cdot \mathrm{ha}^{-1}$ of $\mathrm{P}_{2} \mathrm{O}_{5}$ was analyzed, as well as analysis of variance was applied. As there was significance only for the harvest interval factor, the briquettes were produced by combining samples of the two doses evaluated for each harvest interval.
Data were subjected to analysis of variance (ANOVA) at probability $5 \%(\mathrm{P}<0.05)$. When productivity values, average diameter, basic density, and energy of large branch were significantly influenced by dose factor (six doses), they were subjected to regression analysis. When the values of any variables were influenced only by the harvest interval factor or dose (the two extreme doses, 0 e $320 \mathrm{~kg} \cdot \mathrm{ha}^{-1}$ of $\mathrm{P}_{2} \mathrm{O}_{5}$ ), the averages were compared by Tukey test $(\mathrm{p}<0.05)$. P contents in soil and in LB were subjected to simple linear correlation (r) with growth and energy variables of LB.

\section{RESULTS}

\subsection{Productivity and diameter of mate large branch}

Productivity and average diameter of large branches (LB), arising from mate crop, were influenced by the interaction between dose $P$ and harvest interval (Figures $1 \mathrm{~A}$ and B). Productivity of LB was positively influenced by fertilization when harvests were held at intervals of 24 months, without being affected in crops at intervals of 12 months and with little significant growth in the 18-month interval (Figure 1A). At the harvest interval of 18 months, maximum production of 1.3 t.ha ${ }^{-1}$ of dry LB occurred at a dose of $258 \mathrm{~kg} \cdot \mathrm{ha}^{-1}$ of $\mathrm{P}_{2} \mathrm{O}_{5}$. In harvests with intervals of 24 months, the maximum productivity of $4.1 \mathrm{t} \mathrm{ha}^{-1}$ of LB occurred at the highest dose tested of $\mathrm{P}$.

Average diameter of LB was also greater in the highest harvest interval, with maximum of 12.9, 15.4 and $17.2 \mathrm{~mm}$ at doses of 181, 207 and $203 \mathrm{~kg} \cdot \mathrm{ha}^{-1}$ of $\mathrm{P}_{2} \mathrm{O}_{5}$, respectively, for harvest intervals of 12,18 and 24 months (Figure 1B).

\subsection{Physical and energetic properties of mate large branch}

Basic density (Figure 1C) and gross calorific value (Figure 1D) of LB were influenced only by harvest interval, while energy density of LB was affected by the interaction between dose of $\mathrm{P}$ and harvest interval (Figure 1E). The ash content was not affected by dose of $\mathrm{P}$, nor by harvest interval, and had an overall average of $3.9 \%$.

Basic density was higher at 18-and-24-month harvest intervals ( 0.41 and 0.40 g.cm ${ }^{-3}$, respectively) compared to those of 12 months $\left(0.39 \mathrm{~g} . \mathrm{cm}^{-3}\right)$ (Figure 1C). LB from crops at intervals of 18 and 24 months showed 
A

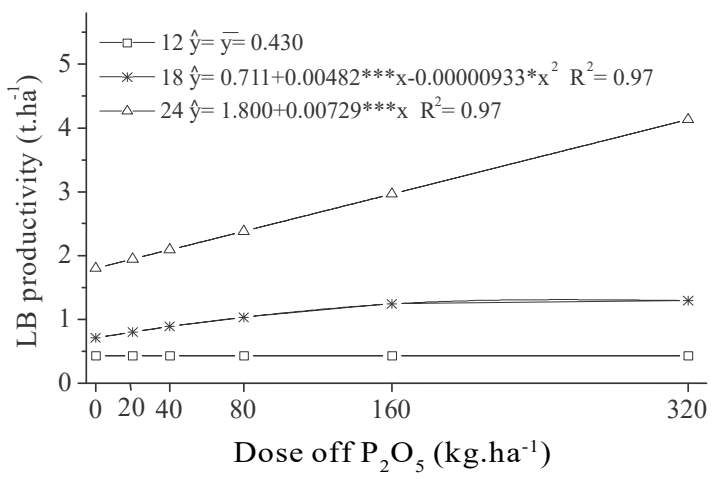

C

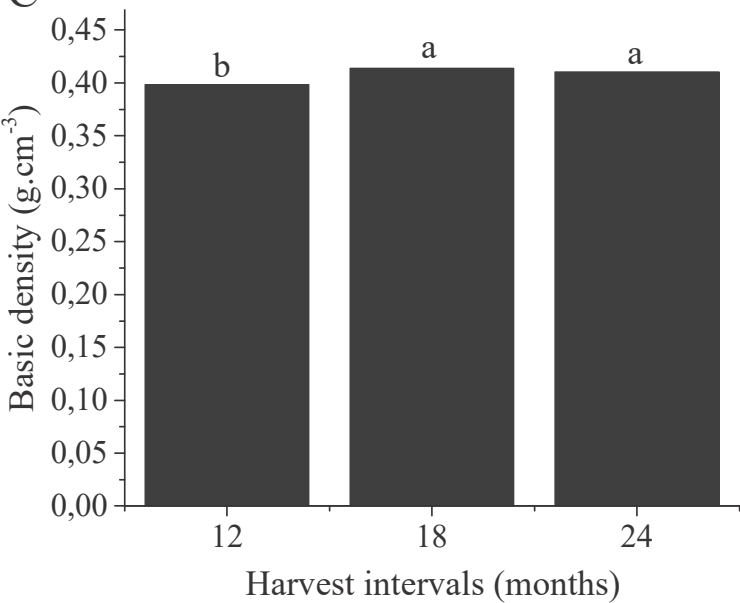

B

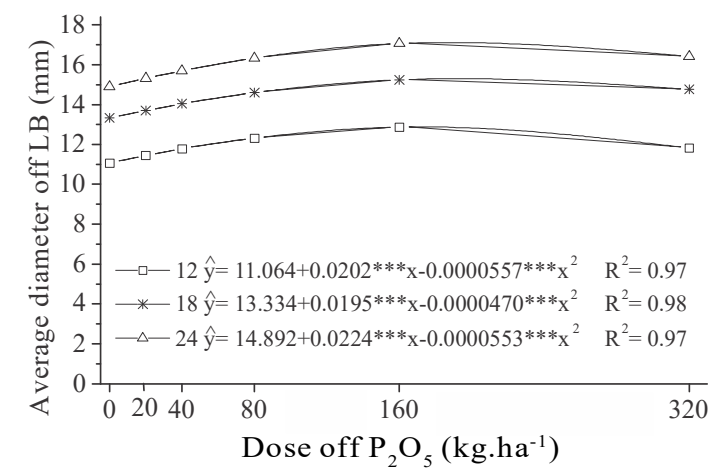

D

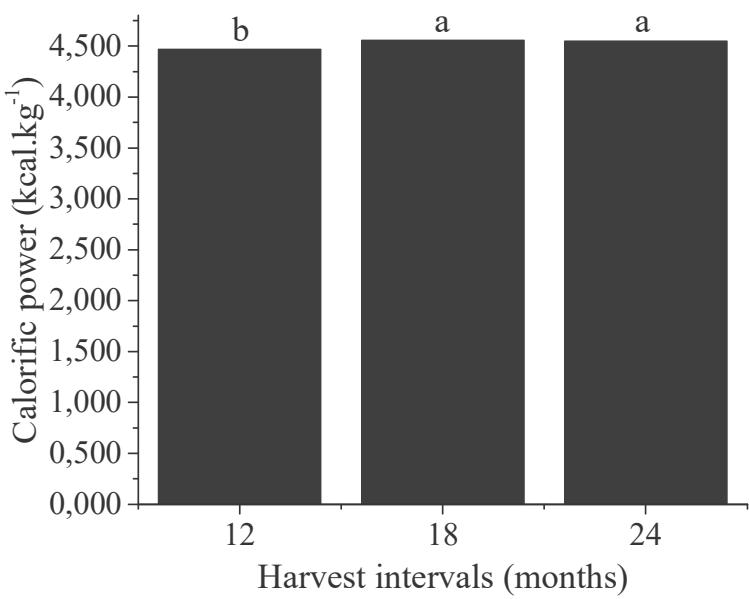

E

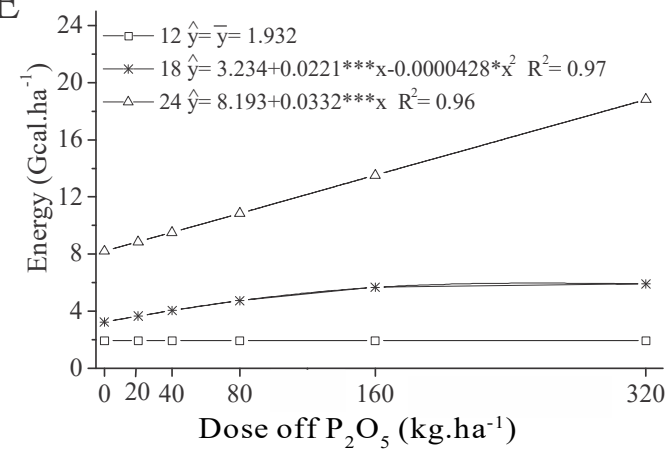

Figure 1 - Yield (A), average diameter (B), wood density (C), calorific power (D) and energy productivity (E) of large branches (LB) of mate plants affected by phosphorus fertilization and harvest intervals. * and ***, respectively, correspond to 5 and $0.1 \%$ significance. The averages followed by the same letter do not vary statistically $(\mathrm{p}<0.05)$, according to the Tukey test.

Figura 1 - Produção (A), diâmetro médio (B), densidade básica (C), poder calorífico superior (D) e energética (E) do galho grosso $(G G)$, resíduo da colheita da erva-mate submetida a adubação fosfatada e colhida em diferentes intervalos de tempo. * $e^{* * *}$, respectivamente, significativo a 5 e 0,1\%. Médias seguidas por uma mesma letra não diferem estatisticamente $(p<0,05)$ pelo teste de Tukey. 
calorific value of 4,550 and 4,558 kcal. $\mathrm{kg}^{-1}$, respectively, which are higher values than those of 12-month intervals $\left(4,468 \mathrm{kcal} . \mathrm{kg}^{-1}\right)$ (Figure 1D).

The amount of power generated per hectare (Figure 1E) varied according to LB productivity, since the doses of $\mathrm{P}$ did not affect calorific value of wood (Figure 1D). The smallest amount of energy generated, with overall average of $1.93 \mathrm{Gcal}^{-h^{-1}}{ }^{-}$, occurred in the lower harvest interval evaluated. At 18 -month interval, the maximum energy of $6.09 \mathrm{Gcal}^{-h^{-1}}$ occurred when $258 \mathrm{~kg} \mathrm{ha}^{-1} \mathrm{P}_{2} \mathrm{O}_{5}$ were applied. For the 24-month harvest interval, the

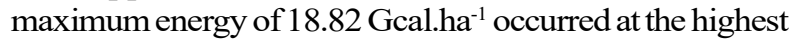
dose of $P$ evaluated.

\subsection{Physical and energetic properties of briquettes}

Maximum tensile strength and energy density were significantly influenced by harvest interval (Table 3 ), while apparent density and gross calorific value, with an average of $0.99 \mathrm{~g} . \mathrm{cm}^{-3}$ and $11,058 \mathrm{kcal} . \mathrm{kg}^{-1}$, respectively, were not affected by harvest intervals.

Maximum tensile strength of briquettes made with mate LB harvested at 12-month interval was higher than for intervals of 18 and 24 months. Briquettes produced

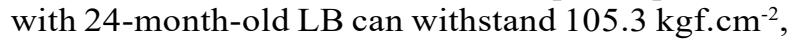
statistically exceeding 71.5 and $71.8 \mathrm{kgf.cm}{ }^{-2}$, respectively, from 12-and-18-month harvest intervals (Table 3). LB harvested at 18-month interval produced briquettes with energy density statistically higher $\left(4.64 \mathrm{Gcal} . \mathrm{m}^{-3}\right)$ than the ones derived from $\mathrm{LB}$ which harvest intervals were 12 (4.37 Gcal.m $\left.\mathrm{m}^{-3}\right)$ and 24 months (4.43 Gcal.m $\left.\mathrm{m}^{-3}\right)$.

\subsection{Correlation between $P$ contents of soil and mate large branch}

The correlation of $\mathrm{P}$ availability in soil and $\mathrm{P}$ content in LB and production indicates high positive correlation only for harvest at intervals of 18 and 24 months (Table 4), while average diameter of LB was positively correlated with $P$ availability in soil and $P$ content in $L B$ at the three evaluated harvest intervals. In contrast, basic density and gross calorific value did not show significant correlation with $\mathrm{P}$ availability in soil and $\mathrm{P}$ content in LB. Ash content was not correlated with any variable evaluated. Energy density was positively correlated with $\mathrm{P}$ availability in soil and $\mathrm{P}$ content in LB only at 18-and-24-month harvest intervals.

\section{DISCUSSION}

Phosphorus fertilization and harvest intervals showed to be determining factors in production of mate large branches (Figure 1A). The lack of response to fertilization at shorter intervals, such as 12 months, can be attributed to the need for more time for plant recovery after harvest impact (Santin, 2013). The main mate product is composed of approximately $70 \%$ of leaves and $30 \%$ of thin branches (diameter $<7.0 \mathrm{~mm}$, approximately), remaining LB in the area. In this kind of crop, it is removed from around 85 to $95 \%$ of the volume of leaves from the crown, which creates an imbalance between leaves and roots, causing the death of some of the latter, which requires a compensatory response from the plant (Milano; Dalcin, 2000). Therefore, at harvest short intervals, the plant also presents small leaf area and low root density, which leads to a reduced photosynthetic rate, with lower demand of $\mathrm{P}$ and lower nutrient absorption capacity (Epstein; Bloom, 2004). At intervals of 18 and 24 months, there is enough time for restoration of the crown and root system, favoring the response to fertilization.

The average diameter of LB showed positive quadratic response with doses of $\mathrm{P}$ at the three harvest intervals assessed (Figure 1B), although, in mass productivity, the response was quadratic only at 18 month interval (Figure 1A). This finding is also reinforced by the fact that the highest correlation coefficient between

Table 3 - Properties of briquettes produced with large branches of mate plants harvested at different harvest intervals. The averages followed by the same letter do not vary statistically $(p<0.05)$, among harvest intervals, according to the Tukey test and ${ }^{\text {ns }}$ not significant.

Tabela 3 - Propriedades de Briquete produzidos de GG da erva-mate colhida em diferentes intervalos de tempo. Médias seguidas por uma mesma letra não diferem estatisticamente $(p<0,05)$ entre intervalos de colheita pelo teste de Tukey e ns não significativo.

\begin{tabular}{|c|c|c|c|c|c|}
\hline $\begin{array}{l}\text { Harvest } \\
\text { Interval }\end{array}$ & $\begin{array}{l}\text { Moisture } \\
\text { Content }\end{array}$ & Bulk density & $\begin{array}{l}\text { Tensile } \\
\text { Strength }\end{array}$ & $\begin{array}{c}\text { Gross calorific } \\
\text { value }\end{array}$ & $\begin{array}{l}\text { Energy } \\
\text { density }\end{array}$ \\
\hline Month & $\%$ & g. $\mathrm{cm}^{-3}$ & kgf. $\mathrm{cm}^{-2}$ & kcal.kg ${ }^{-1}$ & Gcal.m \\
\hline 12 & $10.4 \mathrm{a}$ & & $71.5 b$ & & $4.37 b$ \\
\hline 18 & $10.0 \mathrm{~b}$ & $0.99^{\text {ns }}$ & $71.8 \mathrm{~b}$ & $11.058^{\mathrm{ns}}$ & $4.64 a$ \\
\hline 24 & $9.9 \mathrm{~b}$ & & $105.3 \mathrm{a}$ & & $4.43 b$ \\
\hline
\end{tabular}

Revista Árvore. 2017;41(1):e410110 
Table 4 - Correlation coefficients (r) between soil P content and large branch characteristics of mate plants harvested at different harvest intervals affected by phosphorus doses.

Tabela 4 - Coeficientes de correlação linear simples (r) entre variáveis do solo e do resíduo da colheita (galho grosso) da erva-mate, colhido em diferentes intervalos e submetido a doses de fósforo.

\begin{tabular}{|c|c|c|c|c|c|c|}
\hline \multirow[t]{3}{*}{ Variable $^{/ 1}$} & \multicolumn{6}{|c|}{ Large branch of mate plant variables ${ }^{1}$ harvested at different intervals } \\
\hline & Productivity & Diameter & Basic Density & $\begin{array}{c}\text { Gross calorific } \\
\text { value }\end{array}$ & Energy density & Ash content \\
\hline & t.ha ${ }^{-1}$ & $\mathrm{~mm}$ & g. $\mathrm{cm}^{-3}$ & kcal.kg-1 & Gcal.ha $^{-1}$ & $\%$ \\
\hline & \multicolumn{6}{|c|}{ Harvest interval of 12 months } \\
\hline P soil $/ 2$ & $0.587^{\mathrm{ns}}$ & $0.743 *$ & $-0.105^{\mathrm{ns}}$ & $-0.096^{\mathrm{ns}}$ & $0.587^{\mathrm{ns}}$ & $-0.290^{\mathrm{ns}}$ \\
\hline $\mathrm{P} \mathrm{GG}^{3}$ & $0.490^{\mathrm{ns}}$ & $0.753 *$ & $-0.248^{\mathrm{ns}}$ & $-0.158^{\mathrm{ns}}$ & $0.490^{\mathrm{ns}}$ & $-0.025^{\mathrm{ns}}$ \\
\hline \multirow[t]{2}{*}{ Ash content } & $-0.054^{\mathrm{ns}}$ & $0.111^{\mathrm{ns}}$ & $-0.135^{\mathrm{ns}}$ & $-0.054^{\mathrm{ns}}$ & $-0.014^{\mathrm{ns}}$ & \\
\hline & \multicolumn{6}{|c|}{ Harvest interval of 18 months } \\
\hline P soil ${ }^{/ 2}$ & $0.960 * * *$ & $0.839 * *$ & $0.010^{\mathrm{ns}}$ & $-0.311^{\mathrm{ns}}$ & $0.960 * * *$ & $-0.055^{\mathrm{ns}}$ \\
\hline $\mathrm{P} \mathrm{GG}^{3}$ & $0.858 * *$ & $0.725 *$ & $0.106^{\mathrm{ns}}$ & $-0.340^{\mathrm{ns}}$ & $0.858 * *$ & $0.118^{\mathrm{ns}}$ \\
\hline \multirow[t]{2}{*}{ Ash content } & $-0.130^{\mathrm{ns}}$ & $-0.339^{\mathrm{ns}}$ & $0.213^{\mathrm{ns}}$ & $-0.130^{\mathrm{ns}}$ & $-0.527^{\mathrm{ns}}$ & \\
\hline & \multicolumn{6}{|c|}{ Harvest interval of 24 months } \\
\hline $\mathrm{P}$ solo $^{/ 2}$ & $0.975 * * *$ & $0.778 * *$ & $0.413^{\mathrm{ns}}$ & $-0.382^{\mathrm{ns}}$ & $0.975 * * *$ & $-0.272^{\mathrm{ns}}$ \\
\hline $\mathrm{PGG}^{/ 3}$ & $0.893 * * *$ & $0.702 *$ & $0.322^{\mathrm{ns}}$ & $-0.300^{\mathrm{ns}}$ & $0.893 * * *$ & $-0.250^{\mathrm{ns}}$ \\
\hline Ash content & $-0.363^{\mathrm{ns}}$ & $-0.383^{\mathrm{ns}}$ & $0.282^{\mathrm{ns}}$ & $-0.363^{\mathrm{ns}}$ & $-0.066^{\mathrm{ns}}$ & \\
\hline
\end{tabular}

${ }^{11}$ Variable in the doses of 0 and $320 \mathrm{~kg} \cdot \mathrm{ha}^{-1}$ of $\mathrm{P}_{2} \mathrm{O}_{5} ;{ }^{/ 2}$ availability of $\mathrm{P}$ in the $0-20 \mathrm{~cm}$ layer of the soil; ${ }^{/ 3}$ total content of $\mathrm{P}$ in the plant tissue of the large branch (LB) of mate plant harvesting. *, **, *** correspond to $5,1,0.1 \%$ and ${ }^{\mathrm{ns}}$ not significant.

$\mathrm{P}$ availability in soil and average diameter of LB occurred at 18-month interval (Table 3 ). As there are no reports of LB diameter from mate harvest residue, values of $12.9,15.4$ and $17.2 \mathrm{~mm}$, respectively, for harvest intervals at 12,18 and 24 months, can be taken as reference.

The phosphorus fertilization did not alter basic density or GCV of mate LB. However, the age of the LB harvested influenced these variables significantly (Figure 1C). Vale et al. (2000) also found no change in the basic density and GCV of wood in response to NPK fertilization in E. grandis and Acacia mangium. As plant age advances, the cell wall thickness increases (Vital et al., 1984) and, consequently, the increase of density occurs. Although the evaluated harvest intervals are different in only six months, it was possible to verify the influence of age on wood density of mate LB, with higher density at larger harvest intervals. In other forest species, it has been frequent the finding that wood density increases with the plant age (Soares et al., 2014), which corroborates the results of this work.

Gross calorific value of LB, as well as basic density, was also higher for larger harvest intervals (Figure 1D). According to Carneiro et al. (2014), wood density is one of the major indexes to evaluate the potential of biomass for energy, since the higher the density is, the greater the amount of energy stored per volume unit.
Wood density generally increases with the plant age, as found by Soares et al. (2014) for wood of $E$. grandis $x$ E. urophylla hybrid, with ages ranging from 3 to 7 years, from 0.37 to $0.54 \mathrm{~g} . \mathrm{cm}^{-3}$, and respective GCV between 4,454 and 4,547 kcal. $\mathrm{kg}^{-1}$. LB basic density from mate crop, which ranged from 0.40 to $0.41 \mathrm{~g} . \mathrm{cm}^{-3}$ and PCS between 4,468-4,558 kcal. $\mathrm{kg}^{-1}$, is similar to the one of eucalypts, which accredits this biomass as a renewable source of energy with great potential.

The basic density of 0.40 g. $\mathrm{cm}^{-3}$ of mate LB at the age of 12 months is higher than the $0.37 \mathrm{~g} . \mathrm{cm}^{-3}$ of $E$. grandis $x$ E. urophylla wood at the age of 33 months, which was reported by Soares et al. (2014). This may be related to the growth regime between species. Commonly, slow-growing species tend to present high carbon allocation in the cell walls (Fan et al., 2012), high content of cellulose and lignin (Paula, 1993), high fiber percentage, and low percentage of vessels, which has also a reduced diameter (Guilley; Nepveu, 2003). These characteristics favor the increase of wood density. Mate is a slow-growing species (Carvalho, 2003), which contributes for it to have higher density in relation to some eucalypt species assessed under the age of 36 months, for example. However, it should be noted that dry matter per hectare should be taken into account, i.e., the relation between productivity and basic density in the evaluation of potential species for energy, not only considering an index as a factor in selection. 
The increase of energy per area in the largest harvest intervals (Figure 1E) is directly related to the increase of LB dry mass production, caused by phosphorus fertilization (Figure 1B) and confirmed by high correlation between $\mathrm{P}$ in soil and LB productivity (Table 4 ). This behavior also occurs in $E$. grandis plantations when these are subjected to NPK fertilization, while the increase of energy productivity per area is related to the increase of wood productivity (Vale et al., 2000), since the increase of nutrient availability in soil did not change GCV. Maintaining the GCV of mate LB, even at high doses of $\mathrm{P}$, is an important and desirable feature in the production of biomass energy. This is because it allows the energy standardization of mate LB, within the same harvest interval, regardless of whether this waste comes from plantations nourished with $\mathrm{P}$ or not.

Minerals (ash) do not participate in the combustion process of wood, while high levels of these components reduce GCV (Brand, 2010), being undesirable when wood is intended for bioenergy purposes (Protásio et al., 2011). This is because minerals, besides decreasing calorific value, cause corrosion problems, as well as an increase in ash disposal costs due to the increase in volume generated, and an increase in generation of emission of particulate matter. For LB from mate crop, ash content was not correlated with GCV (Table 4), while P content in LB only correlated positively with growth-related variables. Thus, ash and $\mathrm{P}$ contents did not affect the GCV of mate LB.

The age of mate LB influenced some properties of briquettes, such as moisture content, maximum tensile strength, and energy density (Table 3). Moisture apparently showed an inverse relation with age, in such a way that, the lower the harvest interval is, the higher the moisture content of the briquette. This behavior also occurs in P. taeda wood, with decrease in moisture content caused by increase in age (Furtado et al., 2012). Commonly, wood with lower density tends to have a higher moisture content (Gadelha et al., 2012), which was reflected in briquettes with higher moisture content (Table 3), when they originate from LB crops with smaller harvest interval and lower GCV (Figure 1D). Despite the inverse relation between wood moisture and GCV (Furtado et al., 2012), it was not observed for the briquettes of this work. Considering that residues moisture in production of briquettes must be between 8 and $15 \%$ (Gonçalves et al., 2009), moisture content between 9.9 to $10.4 \%$, found in this study, is another indicative of technical feasibility of using mate LB in production of briquettes.

Briquetting aims to increase the amount of energy per volume unit (Kaliyan; Morey, 2009). In this work, with production of briquettes, it was possible to increase, on average, $143 \%$ in apparent density and $144 \%$ in calorific value, respectively, per unit of area and weight of residues from mate crop.

The maximum load of the briquette produced with LB from 24-month crop was approximately $47 \%$ greater than those from 12-and-18 month intervals (Table 3 ). Briquettes made of mate LB with 12-and-18-month harvest interval showed resistance to maximum load (71.5 and $\left.71.8 \mathrm{kgf} . \mathrm{cm}^{-2}\right)$, on average, greater than briquettes produced with charcoal chaff and bamboo residue (42.0 to $80.4 \mathrm{kgf.cm}{ }^{-2}$ ), as verified by Dias Jr. et al. (2014). According to Quirino et al. (1989), briquettes with a load capacity of around $70 \mathrm{kgf} . \mathrm{cm}^{-2}$ can be considered as having good compressive strength. Briquettes produced with 24-month-old LB, with a tensile strength of $105 \mathrm{kgf.cm}{ }^{-2}$ (Table 3 ), can be considered as having high compressive strength.

With briquetting, the aim is to facilitate the transport of vegetable residues increasingly smaller, standardized and with large stock of energy (Quirino et al., 2012). Even if briquettes made of mate LB, with 18-month harvest interval, were higher than the others in energy density (Table 3 ), the variation between the three harvest intervals was small. This shows that the residue briquetting of mate crop at different ages is possible, since it produces briquettes with small energy variation.

\section{CONCLUSION}

Phosphorus fertilization favor the increase in productivity of mate large branches when they are harvested at higher crop intervals, increasing energy produced per area, without changing basic density and gross calorific value of wood.

The increase in harvest intervals of mate raises basic density and gross calorific value of mate large branches.

Mate large branches and briquettes produced from them show energetic and physical adequate properties and great potential for use as energy. 


\section{AKNOWLEDGEMENT}

Thanks to the agricultural companies Vier Ltda e Baldo S.A., from São Mateus do Sul, in the state of Paraná, Brazil, and Embrapa Florestas de Colombo, Paraná, to the Departament of Soils, and the Panels and Wood Energy Laboratory of the Departamento of Forestry Engineering of UFV, in the state of Minas Gerais, and to CNPq, which together enabled the execution of this work.

\section{REFERENCES}

Associação Brasileira de Normas Técnicas ABNT. NBR 8633: Carvão vegetal determinação do poder calorífico. Rio de Janeiro: 1984. 12p.

Associação Brasileira de Normas Técnicas ABNT. NBR 8112: Carvão vegetal - análise imediata. Rio de Janeiro: 1983. 6p.

Associação Brasileira de Normas Técnicas ABNT. NBR 9484: Compensado - Determinação do teor de umidade. Rio de Janeiro: 1986.

Associação Brasileira de Normas Técnicas ABNT. NBR 11941: Madeira: determinação da densidade básica. Rio de Janeiro: 2003. 6p.

Associação Brasileira de Normas Técnicas ABNT. NBR ISO 11093-9: Papel e cartão - Ensaio de tubetes - Determinação da resistência ao esmagamento. Rio de Janeiro: 2009. 3p.

Barcellos DC, Couto LC, Müller MD, Couto L. O estado-da-arte da qualidade da madeira de eucalipto para produção de energia: um enfoque nos tratamentos silviculturais. Biomassa e Energia. 2005;2(2):141-58.

Berger R. Crescimento e qualidade da madeira de um clone de Eucalyptus saligna Smith sob o efeito do espaçamento e da fertilização [dissertação]. Santa Maria: Universidade de Santa Maria; 2000. 106p.

Brand MA. Energia de biomassa florestal. Rio de Janeiro: Interciência; 2010. 131p.

Brand MA, Stähelin TSF, Ferreira JC, Neves MD. Produção de biomassa para geração de energia em povoamentos de Pinus taeda L. com diferentes idades. Revista Árvore. 2014;38(2):353-60.
Braga JM, De Filippo BV. Determinação espectrofotométrica de fósforo em extratos de solo e plantas. Ceres. 1974;21:73-85.

Carneiro ACO, Castro AFNM, Castro RVO, Santos RC, Ferreira LP, Damásio RAP. et al. Potencial energético da madeira de Eucalyptus sp. em função da idade e de diferentes materiais genéticos. Revista Árvore. 2014;38(2):375-81.

Carvalho PHR. Espécies arbóreas brasileiras. Brasília: Embrapa Informação Tecnológica; Colombo: Embrapa Florestas; 2003. 1039p.

Coelho Jr LM, Rezende JLP, Oliveira AD. Concentração das exportações mundiais de produtos florestais. Ciência Florestal. 2013;23(4):691-701.

De Filippo BV, Ribeiro AC. Análise química do solo; metodologia. $2^{\text {a }}$.ed. Viçosa, MG: UFV, Imprensa Universitária: 1997. 26p. (Boletim de extensão 29).

Dias Júnior AF, Andrade AM, Costa Júnior DS Caracterização de briquetes produzidos com resíduos agroflorestais. Pesquisa Florestal Brasileira. 2014;34(79):225-34

Epstein E, Bloom AJ. Nutrição mineral de plantas: princípios e perspectivas. $2^{\mathrm{a}}$.ed. Londrina: Planta; 2004. 403p.

Fan Z, Zhang S, Hão G, Slik JWF, Cao K. Hydraulic conductivity traits predict growth rates and adult stature of 40 Asian tropical tree species better than Wood density. Journal of Ecology. 2012;100:732-41.

Furtado TS, Ferreira JC, Brand MA, Neves MD. Correlação entre teor de umidade e eficiência energética de resíduos de Pinus taeda em diferentes idades. Revista Árvore. 2012;36(3):577-82

Gadelha FHL, Silva JÁ, Ferreira RLC, Melo IV, Jorge DL, Tavares JA, et al. Rendimento volumétrico e energético de clones de híbridos de Eucalyptus sp. no polo gesseiro do Araripe, PE. Ciência Florestal. 2012;22(2):331-41.

Gonçalves JE, Sartori MMP, Leão AL. Energia de briquetes produzidos com rejeitos de resíduos

Revista Árvore. 2017;41(1):e410110 
sólidos urbanos e madeira de Eucalyptus grandis. Revista brasileira de Engenharia Agrícola e Ambiental. 2009;13(5):657-61.

Guilley E, Nepveu G. Anatomical interpretation of the components of a wood density mixed model in sessile oak (Quercus petraea Liebl.): ring number from the pith, ring width, tree, inter-annual variation, heartwood formation. Annals os Forestry Science. 2003;60:331-46.

Kaliyan K, Morey RV. Factors affecting strength and durability of densified biomass products. Biomass \& Bioenergy. 2009;33(3):337-59.

Sociedade Brasileira de Ciência do Solo - Núcleo Regional Sul - Comissão de Química e Fertilidade do Solo. SBCS/CQFS. Manual de adubação e de calagem para os Estados do Rio Grande do Sul e Santa Catarina. 10 .ed. Porto Alegre: 2004. 400p.

Milano M, Dalcin E. Arborização de vias públicas. Rio de Janeiro: Light; 2000. 206p.

Paula JE. Madeiras da caatinga úteis para produção de energia. Pesquisa Agropecuária Brasileira. 1993;28:153-65.

Protásio TP, Neves TA, Reis AA, Trugilho PF. Efeito da idade e clone na qualidade da madeira de Eucalyptus spp visando à produção de bioenergia. Ciência Florestal. 2014;24(2):465-77.

Protásio TP, Bufalino L, Tonoli GHD, Couto AM, Trugilho PF, Guimarães Júnior M. Relação entre o poder calorífico superior e os componentes elementares e minerais da biomassa vegetal. Pesquisa Florestal Brasileira. 2011;31(66):122-33.

Quirino WF, Vale AT, Andrade APA, Abreu VLS, Azevedo ACS. Poder calorífico da madeira e de resíduos lignocelulósicos. Biomassa e Energia. 2004;1:173-82.

Quirino WF, Pinha IVO, Moreira ACO, Souza F, Tomazello Filho M. Densitometria de raios x na análise da qualidade de briquetes de resíduos de madeira. Scientia Forestalis. 2012;40(96)525-36.

Quirino WF, Fontes PJP, Okino EYA. Aspectos técnicos da briquetagem de carvão no Brasil. Brasília, DF: LPF/IBAMA; 1989. (Série técnica, 1).

Santin D, Wendling I, Benedetti EL, Morandi D, Domingos DM. Sobrevivência, crescimento e produtividade de plantas de erva-mate produzidas por miniestacas juvenis e por sementes. Ciência Florestal. 2015;25(3):571-79.

Santin D. Produtividade e disponibilidade de nutrientes influenciadas pela calagem, adubação NPK e intervalos de colheita em erva-mate [tese]. Viçosa, MG: Universidade Federal de Viçosa; 2013. 104p.

Santin D. Produtividade, teor de minerais, cafeína e teobromina em erva-mate adensada e adubada quimicamente [dissertação]. Curitiba: Universidade Federal do Paraná; 2008. 114p

Soares VC, Bianchi ML, Trugilho PF, Pereira AJ, Höfler J. Correlações entre as propriedades da madeira e do carvão vegetal de híbridos de eucalipto. Revista Árvore. 2014;38(3):543-9.

Vale AT, Brasil MAM, Carvalho CM, Veiga RAA. Produção de energia do fuste de Eucalyptus grandis Hill ex Maiden e Acacia mangium Willd em diferentes níveis de adubação. Cerne. 2000;6:83-8.

Vital BR. Métodos de determinação da densidade da Madeira. Viçosa, MG: SIF; 1984. 21p. (Boletim técnico, 1). 